Pengaruh Kualitas Layanan Pustakawan ... (Anton Risparyanto)

\title{
PENGARUH KUALITAS LAYANAN PUSTAKAWAN TERHADAP LOYALITAS PEMUSTAKA DENGAN VARIABEL INTERVENING KEPUASAN PEMUSTAKA
}

\author{
Anton Risparyanto \\ Pustakawan Universitas Islam Indonesia \\ Anton.risparyanto@yahoo.co.id
}

Kualitas layanan pustakawan sangat berpengaruh signifikan terhadap loyalitas pemustaka melalui mediasi (intervening) kepuasan pemustaka. Apabila kualitas layanan pustakawan baik, maka loyalitas pemustaka yang dimediasi oleh kepuasan pemustaka akan meningkat. Tujuan penelitian ini untuk mengetahui: (1) pengaruh kualitas layanan pustakawan terhadap kepuasan pemustaka; (2) besarnya kontribusi kualitas layanan pustakawan terhadap kepuasan pemustaka; (3) pengaruh kepuasan terhadap loyalitas pemustaka; (4) pengaruh dan kontribusi kualitas layanan pustakawan terhadap loyalitas pemustaka yang dimediasi oleh kepuasan pemustaka. Lokasi penelitian di Direktorat Perpustakaan UII. Data yang dikumpulkan berupa data primer dengan jumlah responden 190. Data ditampilkan dalam bentuk tabel dan dianalisa dengan menggunakan statistik analis regresi. Hasil penelitian menunjukan bahwa: (1) pengaruh kualitas layanan pustakawan terhadap kepuasan pemustaka adalah signifikan; (2) kontribusi kualitas layanan pustakawan terhadap kepuasan pemustaka sebesar 47,8\%; (3) pengaruh kepuasan pemustaka terhadap loyalitas pemustaka signifikan;(4) pengaruh kualitas layanan pustakawan terhadap loyalitas pemustaka dengan mediasi kepuasan pemustaka adalah signifikan dan (5) kontribusi kualitas layanan pustakawan terhadap loyalitas pemustaka yang dimediasi kepuasan pemustaka sebesar 33,1\%.

Kata kunci: Kualitas layanan, pustakawan, pemustaka, kepuasan, loyalitas

\section{Pendahuluan \\ Latar Belakang}

Undang-Undang Republik Indonesia No. 43 tahun 2007 tentang perpustakaan BAB I pasal 1 ayat (1) menyatakan bahwa : perpustakaan merupakan suatu lembaga atau institusi pengelola koleksi karya tulis, karya cetak, dan/atau karya rekam secara profesional dengan sistem yang baku guna memenuhi kebutuhan pendidikan, penelitian, pelestarian, informasi, dan rekreasi para pemustaka. Dengan landasan peraturan tersebut mempunyai arti bahwa perpustakaan merupakan suatu lembaga atau intitusi pengelola informasi tercetak maupun noncetak (digital) yang harus dikelola secara profesional yang berguna untuk kebutuhan pemustaka. Ayat (9) undang-undang tersebut menyebutkan adanya pergantian istilah dari pengguna perpustakaan menjadi pemustaka.
Jadi pengertian pemustaka yaitu perseorangan, kelompok orang, masyarakat atau lembaga yang memanfaatkan fasilitas layanan perpustakaan. Dari keterangan tersebut dapat diartikan bahwa siapa saja yang menggunakan jasa layanan fasilitas perpustakaan secara rutin disebut pemustaka.

Kunjungan pemustaka ke perpustakaan dilakukan kontinyu tanpa memperhitungkan jumlah dan waktu. Yaitu setiap ada kebutuhan pencarian informasi dan koleksi buku selalu menuju ke perpustakaan. Artinya komitmen pelanggan perpustakaan (pemustaka) dalam menjalin hubungan dengan perpustakaan bertahan secara mendalam dan konsisten dimasa yang akan datang serta merekomendasikan kepada teman lain untuk memanfaatkan jasa perpustakaan inilah merupakan perwujudan loyalitas pelanggan (Jasfar, 2012). Disamping itu pemustaka juga 
ikut menyebarkan berbagai kebaikan dan kelengkapan informasi koleksi buku yang dimiliki perpustakaan. D e $\mathrm{ng}$ a $\mathrm{n}$ d e m i kia $\mathrm{n}$ loyalitas pemustaka mempunyai peran yang sangat penting dalam menyebarkan informasi dan koleksi buku yang dimiliki perpustakaan. Mempertahankan pemustaka berarti meningkatkan kinerja dan kualitas layanan pustakawan di perpustakaan. Hal ini menjadi alasan sangat penting mengapa suatu perpustakaan harus mempertahankan pemustaka sebagai pelanggan yang loyal.

Loyalitas pemustaka timbul dengan adanya rasa puas pemustaka dalam memperoleh berbagai macam informasi yang dibutuhkan. Kepuasan pelanggan merupakan perbandingan antara persepsi pelanggan terhadap jasa yang diterima dan harapannya sebelum menggunakan jasa tersebut (Zeithaml dan Bitner dalam Jasfar, 2012). Jadi harapan pelanggan jasa informasi oleh pemustaka minimal sama atau melebihi dan dapat terpenuhi oleh kinerja pustakawan. Pemustaka akan merasa puas terhadap jasa yang disediakan atau kualitas layanan pustakawan. Pustakawan selalu berusaha semaksimal mungkin untuk memenuhi berbagai kebutuhan informasi yang diperlukan oleh pemustaka. Sehingga pemustaka merasa puas dan tidak pernah merasa kecewa terhadap kualitas layanan yang disediakan oleh pustakawan. Sebaliknya apabila kebutuhan informasi yang diperlukan tidak sesuai dengan yang diharapkan oleh pemustaka, maka pemustaka akan merasa kecewa terhadap kualitas jasa yang disediakan oleh pustakawan. Kualitas layanan pustakawan mempunyai peran yang sangat besar dalam mewujudkan kepuasan pemustaka sebagai pengguna jasa informasi. Disamping itu kualitas layanan pustakawan juga merupakan kunci utama keberhasilan dalam layanan jasa informasi. Tanpa adanya kualitas layanan maka kepuasan pemustaka sebagai pengguna jasa informasi tidak akan dapat terwujud. Kualitas layanan merupakan tingkat keunggulan atau upaya pengendalian secara maksimal untuk memenuhi kebutuhan pemustaka (Lasa Hs., 2009). Pustakawan harus dapat meningkatkan kualitas layanan secara maksimal sehingga kepuasan pemustaka akan kebutuhan informasi pemustaka dapat terpenuhi. Sebaliknya apabila kualitas layanan pustakawan tidak maksimal kebutuhan informasi pemustaka kurang terpenuhi sehingga pemustaka mempunyai persepsi buruk terhadap kualitas layanan pustakawan.

Hasil penelitian pendahuluan menyatakan bahwa pengaruh kualitas layanan terhadap kepuasan pemustaka adalah signifikan dan positif (Marguna, 2013). Disamping itu juga banyak buku yang membahas tentang kualitas layanan akan berpengaruh terhadap kepuasan dan loyalitas pelanggan. Disamping itu juga disebutkan bahwa kualitas layanan dari suatu instansi atau perusahaan akan berpengaruh terhadap kepuasan pelanggan (konsumen). Artinya apabila kualitas layanan suatu instansi atau lembaga akan menentukan kepuasan pelanggan atau pemustaka dan berimplikasi terhadap loyalitas untuk melakukan transasksi ulang (Bahrun, 2009; Hurriyati, 2005; Irawan, 2003; Jasfar, 2012;).

Merujuk penjelasan di atas, penelitian ini melakukan kajian yang sangat penting dalam bidang layanan jasa informasi yang terdapat di perpustakaan. Kajian ini mendapat perhatian yang luas para pustakawan sebagai pengelola perpustakaan dan informasi, supaya dapat melakukan layanan baik dan efesien dalam memanjakan pemustaka. Bidang kajian difokuskan pada peningkatan kepuasan dan loyalitas pemustaka melalui kualitas layanan pustakawan Direktorat Perpustakaan Universitas Islam Indonesia (UII). Dengan adanya kualitas layanan yang baik, diharapkan kepuasan pemustaka akan dapat terwujud sehingga berdampak pada loyalitas pemustaka. Sehubungan dengan permasalahan di atas, sehingga timbul rumusan masalah penelitian 
sebagai berikut: (1) apakah signifikan pengaruh kualitas layanan pustakawan terhadap kepuasan pemustaka; (2) berapa kontribusi kualitas layanan pustakawan terhadap kepuasan pemustaka; apakah signifikan pengaruh kepuasan terhadap loyalitas pemustaka; apakah signifikan pengaruh kualitas layanan pustakawan terhadap loyalitas pemustaka yang dimediasi oleh kepuasan pemustaka; berapa kontribusi kualitas layanan pustakawan terhadap loyalitas pemustaka yang dimediasi oleh kepuasan pemustaka.

Atas dasar permasalahan di atas, maka tujuan penelitian untuk mengetahui: (1) pengaruh kualitas layanan pustakawan terhadap kepuasan pemustaka; (2) besarnya kontribusi kualitas layanan pustakawan terhadap kepuasan pemustaka; (3) pengaruh kepuasan terhadap loyalitas pemustaka; (4) pengaruh dan kontribusi kualitas layanan pustakawan terhadap loyalitas pemustaka yang dimediasi oleh kepuasan pemustaka. Manfaat dari penelitian ini untuk memberikan masukan kepada lembaga sebagai bahan dasar pengembangan konseptual yang berkaitan dengan peningkatan kualitas layanan pustakawan.

Permasalahan ini sudah pernah dilakukan penelitian oleh Tamara (2014) tentang pengaruh kualitas layanan terhadap kepuasan dan loyalitas pemustaka di Perpustakaan Nasional Republik Indonesia. Dengan menggunakan metode analisis Structural Equation Modeling (SEM) yaitu metode teknik statistik yang digunakan untuk menganalisis hubungan antar variabel laten dengan variabel teramati sebagai indikatornya, hubungan antar variabel laten, serta kesalahan pengukuran. Hasil analisis menyatakan kualitas layanan perpustakaan secara langsung maupun tidak langsung berpengaruh signifikan terhadap kepuasan dan loyalitas pemustaka. Begitu pula pengaruh variabel kepuasan signifikan terhadap loyalitas pemustaka. Ada enam faktor kualitas layanan perpustakaan yang secara langsung maupun tidak langsung mempengaruhi terhadap kepuasan dan loyalitas pemustaka. Ada empat faktor variabel laten yang mempengaruhi tingkat siginifikan diantaranya: sumber daya elektronik, layanan lain, lingkungan perpustakaan dan sisi manusia, sedangkan variabel lainya yaitu publikasi cetak dan fasilitas teknik tidak signifikan. Masalah ini kami lakukan lagi dengan obyek berbeda yang fokus pada variabel independent jasa kualitas layanan pustakawan dari sisi sumber daya manusia. Ada beberapa pengertian yang digunakan dalam menjelaskan masalah pengaruh kualitas layanan pustakawan terhadap kepuasan dan loyalitas pemustaka seperti yang diuraikan dibawah ini.

\section{Pengertian Loyalitas Pelanggan (Pemustaka)}

Menurut Lasa (2009) setiap orang atau lembaga yang berkunjung ke perpustakaan ingin memanfaatkan berbagai fasilitas atau layanan perpustakaan yang tersedia baik secara langsung maupun tidak langsung seperti layanan koleksi buku, pandang dengar, rujukan cepat layanan cepat dan berbagai jenis layanan yang tersedia lainnya disebut pengguna perpustakaan (pemustaka). Orang atau lembaga yang secara rutin membeli produk atau jasa perpustakan disebut pelanggan (Sihaabudin Qalubi, dkk., 2007). Berdasarkan pernyataan tersebut dapat diartikan orang atau lembaga yang memanfaatkan pembelian produk atau jasa perpustakaan secara rutin merupakan pelanggan (pemustaka).

Loyalitas secara umum merupakan kesetiaan seseorang atas suatu produk, baik barang maupun jasa tertentu (Foedjawati dalam Pratiwi, 2010). Senada dengan pendapat (Griffin dalam Musanto, 2004) bahwa seseorang pelanggan dikatakan setia atau loyal apabila pelanggan tersebut menunjukkan perilaku pembelian secara teratur atau terdapat suatu kondisi dimana mewajibkan pelanggan membeli paling sedikit dua kali dalam selang waktu tertentu. Faktor- 
faktor yang berpengaruh dalam penentuan pilihan seperti tingkat harga, jarak, kualitas dan atribut lainnya tidak lagi dipertimbangkan oleh seorang pelanggan yang loyal.

Loyalitas pelanggan merupakan suatu komitmen yang mendalam dari pelanggan untuk melakukan pembelian ulang suatu barang atau jasa yang disukai secara konsisten dimasa yang akan datang. Menurut Jasfar (2012) definisi loyalitas pelanggan yaitu keinginan pelanggan untuk melakukan pembelian kembali suatu barang atau jasa setelah mengetahui kualitas barang atau jasa sehingga timbul keinginan untuk merekomendasikan kepada orang lain agar melakukan pembelian barang atau menggunakan jasa yang sama dengan yang dimaksud pelanggan. Loyalitas pelanggan merupakan kesediaan pelanggan untuk berlangganan terus pada suatu jasa atau perusahaan dalam jangka waktu panjang, dengan membeli dan menggunakan secara berulang ulang (Lovelock dan Wrikght dalam Jasfar, 2015). Loyalitas pelanggan merupakan komitmen pelanggan bertahan secara mendalam untuk berlangganan kembali atau melakukan pembelian ulang produk/jasa terpilih secara konsisten dimasa yang akan datang, meskipun pengaruh situasi dan usaha-usaha pemasaran mempunyai potensi untuk menyebabkan perubahan perilaku (Oliver dalam Hurriyati, 2005). Loyalitas pelanggan merupakan reaksi atau akibat dari terciptanya kepuasan pelanggan sebagai implementasi dari keberhasilan pelayanan yang berkualitas dalam memenuhi harapan pelanggan (Pratiwi, 2010). Pelanggan loyal adalah mereka yang antusias terhadap suatu merek atau produk yang digunakannya. Pelanggan yang loyal kepada keputusan pembeliannya, tidak lagi mempertimbangkan faktor-faktor yang berpengaruh dalam penentuan pilihan karena telah tertanam dalam dirinya bahwa produk atau jasa yang dibeli sesuai dengan harapan dan kebutuhan. Loyalitas pelanggan mencerminkan niatan berperilaku (intended behavior) berkenaan dengan suatu produk atau jasa. Niatan berperilaku di sini mencakup kemungkinan pembelian mendatang atau pembaharuan kontrak jasa atau sebaliknya, juga seberapa mungkin pelanggan akan beralih ke penyedia layanan atau merek lainnya (Selnes dalam Sinaga, 2010). Loyalitas pelanggan merupakan manifestasi dan kelanjutan dari kepuasan konsumen dalam menggunakan fasilitas maupun jasa pelayanan yang diberikan oleh perusahaan, serta untuk tetap menjadi konsumen dari perusahaan tersebut. Sedangkan menurut (Jacoby dan Olson dalam Pratiwi, 2010) menjelaskan pengertian loyalitas pelanggan menekankan pada runtutan pembelian, proporsi pembelian dan probabilitas pembelian.

Memahami kebutuhan dan keinginan pelanggan, merupakan hal penting yang dapat mempengaruhi loyalitas pelanggan. Pelanggan yang tidak loyal akan menginformasikan dua kali lebih hebat kepada orang lain tentang pengalaman buruknya tentang produk atau jasa yang dia terima, sedangkan pelanggan yang loyal akan menginformasikan tentang hal-hal yang terbaik. Oleh karena itu, pelanggan yang loyal merupakan aset yang berharga.

\section{Karateristik Loyalitas Pelanggan (Pemustaka)}

Di dalam pasar yang persaingannya sangat ketat, banyak alternative merek, harga bervariasi, dan banyak produk pengganti, maka loyalitas merek pada umumnya cenderung menurun. Oleh karena itu perusahaan yang ingin tetap bertahan perlu mengembangkan strategi pemasaran, dengan harapan konsumen tetap memiliki loyalitas terhadap produk atau jasa dari perusahaan tersebut. Pelanggan yang loyal sangat besar artinya bagi perusahaan karena pelanggan yang loyal berarti kelangsungan hidup perusahaan dan meningkatkan profitabilitas perusahaan. Sejalan dengan itu (Yuda Wicaksana dalam 
Pratiwi, 2010:42) menjelaskan loyalitas pelanggan mempunyai karakteristik atau ciri-ciri sebagai berikut:

a. Pelanggan yang melakukan kunjungan atau pembelian ulang pada tempat yang sama secara teratur.

b. Pelanggan konsisten terhadap tempat pembelian walaupun produknya berbeda.

c. Pelanggan selalu mereferensikan kepada orang lain untuk melakukan pembelian pada tempat yang sama.

d. Pelanggan tidak mudah terpengaruh atau tertarik pada pesaing tempat lain. untuk pindah melakukan pembelian.

Definisi Konsep Loyalitas Pelanggan (Pemustaka). Apabila kita melakukan penelusuran terhadap berbagai definisi tentang loyalitas pelanggan diatas maka definisi konsep loyalitas pemustaka yaitu kesetiaan pemustaka yang selalu melakukan kunjungan dan pembelian jasa (pencarianan informasi, peminjaman dan pengembalian koleksi buku) secara teratur, kontinyu dan konsisten di perpustakaan serta selalu berusaha merekomendasikan kepada semua teman untuk me manfaatkan jasa informasi yang tersedia, walaupun informasi dan buku yang dicari dapat ditemukan di tempat lain.

\section{Pengertian Kepuasan Pelanggan (Pemustaka)}

Kepuasan pelanggan perpustakaan

(pemustaka) merupakan pemenuhan kebutuhan minimum atau keseimbangan antara harapan dengan kinerja. Pelanggan perpustakaan berharap kebutuhan minimum barang atau jasa dapat terpenuhi, bahkan melebihi dari yang diharapkan sehingga akan merasakan adanya suatu kepuasan. Sebaliknya apabila kebutuhan minimum tidak dapat terpenuhi maka pelanggan merasa tidak puas bahkan akan merasa kecewa. Kepuasan pelanggan merupakan persepsi pemikiran pembeli yang merasakan adanya kesamaan antara harapan dibandingkan dengan pengorbananyang dilakukan (Fandy Tjiptono, 2004:349). Kepuasan pelanggan juga merupakan tingkat perasaan seseorang setelah membandingkan antara harapan dengan hasil kinerja seseorang (Philip Kotler dan Gary Amstrong, 2004). Sehingga kepuasan pelanggan merupakan kesesuaian perbandingan antara harapan dengan hasil kinerja yang diperolehnya. Apabila kualitas barang atau jasa yang diperoleh sesuai bahkan melebihi dari yang diharapkan maka pelanggan akan puas. Tetapi sebaliknya pelanggan merasa tidak puas apabila jasa yang diterima tidak sesuai atau lebih kecil dari yang diharapkan.

Menurut Zeithaml dan Bitner dalam Farida Jasfar (2012). Kepuasan pelanggan merupakan perbandingan persepsi pelanggan antara sebelum dan sesudah menggunakan jasa yang diterimanya dengan dipengearuhi oleh beberapa faktor diantaranya: (1) aspek jasa, Penilaian pelanggan tentang jasa akan berpengaruh secara signifikan terhadap kepuasan pelanggan; (2) emosi/perasaan pelanggan , akan memepengaruhi persepsi kepuasan pelanggan jasa; (3) keberhasilan dan kegagalan jasa, pelanggan kadang dikagetkan oleh sebuah hasil jasa lebih baik atau lebih buruk dari yang diharapkan; (4) aspek persepsi atas persamaan keadilan, pelanggan kadang akan bertanya apakah saya sudah diberlakukan secara adil terhadap pelanggan yang lain; (5) aspek pelanggan lain. Kepuasan pelanggan juga akan diceritakan kepada keluarga atau teman lain. Selanjutnya Philip Kotler (2001) mendefinisikan kepuasan pelanggan merupakan penilaian lebih atau setara terhadap penyedia layanan jasa sehubungan dengan terpenuhinya kebutuhan pelanggan. Dengan demikian maka kepuasan pelanggan merupakan kesesuaian antara harapan dengan kinerja layanan, bahkan merupakan tingkat perasaan pelanggan setelah membandingkan antara kinerja atau hasil yang dirasakan dengan harapan. Disamping itu juga menyatakan kepuasan merupakan fungsi dari 
kinerja yang dirasakan (perceivedperformance) dan harapan (expectations). Jika kinerja produk atau jasa lebih rendah dari harapan maka pelanggan akan kecewa tetapi jika kinerja kinerja sesuai harapan bahkan melebihi dari harapan maka pelanggan akan merasa sangat puas. Lebih lanjut lagi pelanggan akan mengatakan sangat puas apabila kualitas jasa yang diperoleh melebihi dari yang diharapkan.

\section{Pengukuran Kepuasan Pelanggan (Pemustaka).}

Kepuasan pelanggan merupakan aset utama yang dapat mendatangkan keuntungan suatu perusahaan atau lembaga penyedia jasa. Apabila pelanggan merasa puas terhadap kualitas barang atau jasa yang diterimanya, maka pelanggan akan melakukan pembelian ulang dan menceritakan kepada pihak lain berbagai hal kebaikan suatu barang atau penyedia jasa. Tetapi apabila tidak puas maka diceritakan oleh pelanggan adalah kejelekan dari kualitas barang atau penyedia jasa. Untuk mengetahui kepuasan pelanggan penting sekali dilakukan pengukuran. Adapun alat ukur kepuasan pelanggan menurut Kotlerdan Amstrong (2004) diantaranya yaitu: (1) Sistem penanganan keluhan dan saran secara cepat dari pelanggan, sehingga tidak menimbulkan kekecewaanterhadap pelanggan. (2) Perusahaan melakukan survei kepuasan pelanggan untuk mengetahui apakah pelanggan sudah merasa puas atau belum. (3) Menempatkan karyawan sebagai penyamar dalam pengguna jasa dengan tujuan untuk mengetahui apakah jasa produk yang diberikan telah sesuai dengan standar perusahaan. (4) Melakukan analisis terhadap pelanggan yang hilang atau pergi untuk mencari informasi ditempat lain. Selanjutnya Lena Elitan dalam Pratiwi, ( 2010:55) menyebutkan indikator alat ukur untuk mengetahui kepuasan pelanggan diantaranya yaitu : (1) Tidak ada keluhan atau keluhan yang teratasi. (2) Perasaan puas pelanggan pada keseluruhan produk. (3) Kesesuaian dengan harapan pelanggan.

\section{Definisi Konsep Kepuasan Pemustaka}

Berdasarkan beberapa pengertian kepuasan pelanggan diatas dapat dilakukan penelusuran untuk memperoleh definisi konsep kepuasan pemustaka yaitu persepsi atau tanggapan pemustaka setelah melakukan evaluasi adanya kesetaraan atau nilai lebih perbandingan antara harapan dengan kinerja yang diperoleh pemustaka. Apabila harapan yang diperoleh pemustaka sesuai atau melebihi dengan hasil kinerja maka pemuska akan merasa puas, tetapi sebaliknya apabila harapan lebih kecil dari kinerja penyedia jasa maka pemustaka akan kecewa.

\section{Pengertian Kualitas Layanan Pustakawan}

Pelanggan perpustakaan secara umum diartikan sebagai pemustaka yang selalu berkunjung ke perpustakaan. Pemustaka membutuhkan layanan jasa informasi yang berkualitas. Layanan jasa informasi berkualitas merupakan suatu keinginan dan harapan pelanggan yang harus selalu terpenuhi kebutuhannya serta ketepatan penyampaian sesuai dengan yang diharapkan (Fandy Tjiptono, 2006). Apabila jasa informasi yang disampaikan pustakawan dapat memenuhi kebutuhan, maka pemustaka akan merasa puas dan jasa informasi dikatakan ideal. Tetapi apabila layanan pustakawan tidak dapat memenuhi kebutuhan informasi pemustaka, maka kualitas jasa layanan pustakawan mempunyai persepsi buruk. Artinya kepuasan layanan jasa informasi pemustaka ditentukan oleh kualitas layanan pustakawan.

Kualitas layanan pustakawan dapat ditingkatkan melalui berbagai upaya diantaranya melakukan kontak lansung terhadap pelanggan. $\mathrm{Hal}$ ini sangat penting sekali dilakukan, karena dengan adanya kontak langsung maka pustakawan dapat memenuhi kebutuhan pemustaka sesuai dengan yang diharapkan. Ini merupakan bentuk layanan unggul (service excellent) terhadap pemuska. Yaitu suatu sikap pustakawan dalam melakukan 
layanan terhadap pelanggan (pemustaka) secara memuaskan. (Elhaitamy dalam Tjiptono, 2005). Empat teknik yang dapat digunakan untuk melakukan layanan unggul (William B., 2004) antara lain:

a. Sikap positip dalam melakukan layanan akan memberikan kesan yang sangat baik terhadap pelanggan.

b. Pelayanan mengetahui kebutuhan pelanggan

c. Kebutuhan pelanggan akan terpenuhi apabila tersedia bahan yang dilayankan.

d. Mempunyai sifat optimis bahwa pelanggan akan kembali lagi.

Menurut beberapa penulis khusus tentang jasa seperti: Zeithhaml, Parasurahman dan Berry sebagaimana dalam (Tjiptono, 2005) menyatakan ada sepuluh jenis yang dapat meningkatkan kualitas layanan jasa yaitu:

a. Berwujud (tangibles) yaitu penampilan pustakawan yang menarik dalam melakukan penataan ruang dan peralatan sehingga terlihat nyaman.

b. Kehandalan (reliability) yaitu kinerja pustakawan yang akurat dan handal sehingga dapat menekan kesalahan sekecil mungkin.

c. Daya tanggap (responsiveness) merupakan jawaban pustakawan terhadap berbagai jenis pertanyaan pemustaka secara cepat dan akurat serta dapat menunjukan ke tempat lain apabila tidak ditemukan.

d. Kompetensi yang dimiliki pustakawan dapat memberikan layanan maksimal.

e. Kenyamanan perpustakan dan sarana komunikasi akan mempercepat dalam melakukan pelacakan informasi.

f. Sikap sopan, ramah, tanggap, dan bersahabat terhadap pemustaka merupakan perilaku pustakawan. Perilaku (courtesy) setiap pustakawan harus bersikap sopan, bersahabat, tanggap, dan ramah kepada pemustaka.

g. Komunikasi (communication). Pustakawan harus tanggap dan mau menerima aspirasi dan mendengarkan masukan dari pemustaka. Sikap ini merupakan bentuk komunikasi yang harus dimiliki pustakawan.

h. Pustakawan memiliki sifat jujur dan kredibel dalam melakukan layanan informasi.

i. Keamanan (security) merupakan, jaminan perpustakaan terhadap barang-barang yang dianggap berharga oleh mahasiswa selama berada di perpustakaan.

Sepuluh jenis yang akan menjadikan pustakawan berkualitas tersebut dapat dikelompokkan menjadi lima dimensi yaitu: (1) bukti fisik (tangibles) seperti (kemampuan berkomunuikasi, penampilan, keterampilan, kecepatan, keahlihan, pengetahuan, pengenalan, sikap pustakawan terhadap pemustaka, kejujuran); (2) kehandalan (reliability) yaitu, pustakawan mampu memberikan pelayanan terhadap pemustaka; (3) Responsif, adanya rasa tanggap dan dapat melakukan layanan secara cepat; (4). Jaminan (assurance), pustakawan mempunyai kemampuan dalam meyakinkan pemustaka; (5) Empati (empathy), pustakawan sangat perhatian terhadap pemustaka dalam melakukan layanan.

\section{Hipotesa Penelitian}

Hipotesa merupakan dugaan atau jawaban sementara suatu penelitian sebelum diadakan pembuktian melalui uji hipotesis. Adapun hipotesis yang diajukan oleh peneliti antara lain:

H1a: Pengaruh kualitas layanan pustakawan terhadap kepuasan pemustaka signifikan.

H1b: Pengaruh kualitas layanan pustakawan terhadap kepuasan pemustaka tidak signifikan.

H2a: Pengaruh kepuasan terhadap loyalitas pemustaka signifikan.

H2b: Pengaruh kepuasan terhadap loyalitas pemustaka tidak signifikan.

H3a: Pengaruh kualitas layanan pustakawan 
terhadap loyalitas pemustaka signifikan.

H3b: Pengaruh kualitas layanan pustakawan terhadap loyalitas pemustaka tidak signifikan.

\section{Penggunaan Metode Penelitian}

Variabel-variabel yang digunakan dalam penelitian ini terdiri dari tiga variabel yaitu kualitas layanan pustakawan sebagai variabel bebas (independent), loyalitas pemustaka sebagai variabel terikat (dependent) dan kepuasan pemustaka sebagai variabel mediasi (intervening). Ketiga variabel tersebut mempunyai hubungan korelasi dan saling berpengaruh secara langsung maupun tidak langsung antara variabel yang satu dengan yang lain. Variabel kualitas layanan secara langsung maupun tidak langsung berpengaruh terhadap variabel loyalitas pemustaka dengan dimediasi oleh variabel kepuasan pemustaka. Sedangkan variabel kepuasan pemustaka sendiri secara langsung juga dipengaruhi oleh variabel kualitas layanan pustakawan dan juga berpengaruh secara langsung terhadap variabel loyalitas pemustaka. Hubungan dan pengaruh antara variabel kualitas layanan terhadap loyalitas pemustaka dapat secara langsung maupun tidak langsung.

Populasi dalam penelitian ini yaitu pemustaka yang berkunjung memanfaatkan Direktorat Perpustakaan Universitas Islam Indonesia dan memanfaatkan layanan pustakawan. Jumlah sampel yang diambil sebanyak 190 responden dengan menggunakan metode probabilitas sampling. Pengambilan sampel dilakukan selama satu minggu dengan menggunakan kuesioner yang berisi diskriptor variable kualitas layanan pustakawan, kepuasan dan loyalitas pemustaka.

Analisa data statitistik yang digunakan regresi linier berganda dengan rumus persamaan sebagai berikut:

$$
\begin{aligned}
& Y 1=\beta 0+\beta 1 X 1+e \\
& Y 2=\beta 0+\beta 1 X 1+X 2+e
\end{aligned}
$$

Keterangan : $\beta 0, \beta 1, \beta 2=$ Koefisien dan $e=$ Error
Term

X1 = Kualitas Layanan Pustakawan (variabel independent)

Y1, X2 = Kepuasan Pemustaka (variabel intervening)

Y2 = Loyalitas Pemustaka (variabel dependent)

Besarnya kontribusi parameter $\beta 1$ dan $\beta 2$ terhadap Y 2 dihitung dengan menggunakan rumus persamaan sebagai berikut :

$\boldsymbol{R}^{2}=\frac{\sum\left(\dot{Y}_{i}-\mathrm{Y}\right)^{2}}{\sum\left(\mathrm{Y}_{i}-\mathrm{Y}\right)^{2}}=\frac{E S S}{T S S}=\frac{\sum \dot{y}^{2}}{\sum \dot{y}^{2}}=\frac{\beta_{1}^{2} \sum x_{i}^{2}}{\sum y_{i}^{2}}=\beta_{1}^{2}\left(\frac{\sum x_{i}^{2}}{\sum y_{i}^{2}}\right)$

Keterangan: $\mathbf{R}=$ Besarnya hubungan

$X_{1}=$ Variabel independent

X2 = Variabel Independent

$Y_{i}=$ Variabel dependent.

Hipotesis regresi linier berganda parameter $\boldsymbol{\beta} 1$ dan $\boldsymbol{\beta} 2$ terhadap $\mathbf{Y} \mathbf{2}$ diuji dengan $p$ menggunakan dua bentuk yaitu pengujian secara individu (parsial) dari masing-masing parameter $\boldsymbol{\beta} 1$ dan $\beta 2$ untuk mengetahui tingkat signifikan terhadap terhadap variabel independent $(\mathrm{Y})$ dan pengujian hipotesis secara serentak (stimulan) antar $\beta 1$ dan $\beta 2$ yang mempengaruhi variable independent $(\mathrm{Y})$.

\section{Hasil Penelitian dan Pembahasan \\ Analisis Statistik Deskriptif}

Dalam penelitian ini analisis statistik deskriptif dilihat menggunakan nilai rata-rata dan standar deviasi. Hasil analisis statistik deskriptif dalam penelitian ini dapat dilihat dalam tabel 1 . di bawah ini : 
Pengaruh Kualitas Layanan Pustakawan ... (Anton Risparyanto)

Tabel 1.

Descriptive Statistics

\begin{tabular}{|c|c|c|c|}
\hline & Mean & Std. Deviation & $\mathrm{N}$ \\
\hline $\begin{array}{c}\text { Kualitas Layanan } \\
\text { Pustakawan }\end{array}$ & 21,4603 & 2,74536 & 189 \\
\hline $\begin{array}{c}\text { Kepuasan } \\
\text { Pemustaka }\end{array}$ & 59,5979 & 7,48667 & 189 \\
\hline $\begin{array}{c}\text { Loyalitas } \\
\text { Pemustaka }\end{array}$ & 20,6720 & 2,56994 & 189 \\
\hline
\end{tabular}

Sumber: Data Primer Olahan SPSS, 2016

Hasil analisis deskriptif pengukuran data yang diambil dari 189 responden sebagaimana tercantum pada tabel 1. diatas, maka dapat disimpulkan sebagai berikut:

a. Nilai rata-rata untuk variabel Kualitas Layanan Pustakawan sebesar 63,8276 dengan standar deviasi 21,4603.

b. Nilai rata-rata untuk variabel Kepuasan Pemustaka 59,5979 dengan standar deviasi 7,48667

c. Nilai rata-rata untuk variabel Loyalitas Pemustaka sebesar 20,6720 dengan standar deviasi 2,56994

\section{Pengaruh dan Kontribusi Kualitas Layanan Pustakawan terhadap Kepuasan Pemustaka.}

Kepuasan pemustaka yaitu persepsi atau tanggapan pemustaka setelah melakukan evaluasi adanya kesetaraan atau nilai lebih perbandingan antara harapan pemustaka dengan kinerja layanan pustakawan. Apabila harapan yang diperoleh pemustaka sesuai atau melibihi dengan hasil kinerja pustakawan maka pemustaka akan merasa puas, tetapi sebaliknya apabila harapan lebih rendah dan tidak sesuai dengan kinerja pustakawan sehingga pemustaka kurang puas. Tinggi dan rendahnya tingkat kepuasan pemustaka secara langsung ditentukan oleh besarnya nilai kualitas layanan pustakawan yang diberikan terhadap pemustaka. Artinya semakin tinggi baik kualitas layanan pustakawan diberikan kepada pemustaka maka akan semakin puas. Sehingga kualitas layanan pustakawan mempunyai pengaruh signifikan dan positif terhadap kepuasan pemustaka. Berdasarkan hasil uji signifikan dengan menggunakan program SPSS sebagaimana tercantum pada tabel 3 . coefficients $^{a}$ penelitian dengan variabel penelitian pengaruh kualitas layanan pustakawan terhadap kepuasan pemustaka diperoleh nilai Sig 0,000 lebih kecil dari pada 0.005 (P-value $<0,005$ ). Ini mempunyai arti bahwa pengaruh kualitas layanan pustakawan terhadap kepuasan pemustaka adalah signifikan dan positif. Hasil ini sejalan dengan penelitian yang dilakukan oleh (Nyoman Oka Dharma, dkk, 2013) yang menyatakan kualitas layanan pustakawan mempunai pengaruh positif dan signifikan terhadap kepuasan pemustaka. Sehingga besarnya tingkat kepuasan pemustaka berkunjung ke perpustakaan dapat diukur dan dijelaskan melalui indikator kualitas layanan pustakawan. Hal ini dapat dimaknai semakin baik dan tinggi kualitas layanan pustakawan maka kepuasan pemustaka semakin tinggi, tetapi sebaliknya apabila layanan pustakawan jelek maka kepuasan pemustaka semakin menurun dan tidak puas. Selanjutya (Mirajtannia Perwita Sari, dkk, 2014) menyatakan kualitas layanan pustakawan mempunyai pengaruh signifikan terhadap kepuasan pelanggan dengan kontribusi sebesar 58,8\%.

Tingkat signifikan pengaruh kualitas layanan pustakawan akan menentukan besar dan kecilnya kontribusi terhadap kepuasan pemustaka. Semakin besar nilai signifikan pengaruhnya maka akan semakin besar pula kontribusinya. Berdasarkan hasil uji regresi sebagai mana tercantum dalam tabel 2. Model Summary ${ }^{a}$ besarnya kontribusi kualitas layanan pustakawan yang ditunjukan melalui beberapa bukti langsung kemampuasn pustakawan dalam melakukan layanan secara handal pustakawan sehingga dapat memberikan jaminan terhadap kepuasan pemustaka diperoleh R Square $(0,478 \times 100)$ sebesar $47,8 \%$ apabila diukur 
dari kepuasan pemustaka. Sedangkan sisanya 52,2\% merupakan berbagai faktor yang berasal dari luar variabel yang tidak disebutkan dalam penelitian ini.

Tabel 2. Model Summarya

\begin{tabular}{|c|c|c|c|c|}
\hline Model & $\mathrm{R}$ & $\mathrm{R}$ Square & $\begin{array}{c}\text { Adjusted } \\
\text { R Square }\end{array}$ & $\begin{array}{c}\text { Std. Error of } \\
\text { the Estimate }\end{array}$ \\
\hline 1 &, $691 \mathrm{a}$ &, 478 &, 475 & 1,98917 \\
\hline
\end{tabular}

Sumber: Data Primer Olahan SPSS, 2016

Berdasarkan hasil pembahasan yang dilakukan melalui uji regeresi dan uji signifikan dapat disimpulkan pengaruh kualitas layanan pustakawan terhadap kepuasan pemustaka adalah signifikan dan positif dengan kontribusi sebesar 47,8\% apabila diukur dari kepuasan pemustaka. Artinya besar dan kecilnya tingkat kepuasan pemustaka ditentukan oleh kualitas layanan pustakawan. Sehingga semakin baik kualitas layanan pustakawan semakin puas pemuastaka dalam menerima layanan.

Tabel 3. Coefficients ${ }^{a}$

\begin{tabular}{|c|c|c|c|c|c|c|}
\hline & Model & $\begin{array}{r}\text { Unsta } \\
\text { Coe }\end{array}$ & $\begin{array}{l}\text { dardized } \\
\text { icients }\end{array}$ & $\begin{array}{l}\text { Standardized } \\
\text { Coefficients }\end{array}$ & t & $\mathrm{Sig}$ \\
\hline & & B & Std. Error & Beta & & \\
\hline & (Constant) & 6,354 & 1,164 & & 5,459 & ,000 \\
\hline 1 & $\begin{array}{l}\text { Kualitas } \\
\text { Layanan }\end{array}$ & ,253 & ,019 & 691 & 13,081 & , 000 \\
\hline
\end{tabular}

Sumber: Data Primer Olahan SPSS, 2016

Hasil uji regresi sebagaimana tercantum pada tabel 3. Coefficients ${ }^{\mathrm{a}}$ diperoleh persamaan regresi linier sederhana $Y=6,354+0,691 X_{1}$. Persamaan ini menjelaskan besarnya kepuasan pemustaka selalu ditentukan oleh kualitas layanan pustakawan. Artinya besarnya nilai konstanta 6,354 merupakan nilai kepuasan pemustaka sebagai variabel independent akan selalu tetap apabila tidak terjadi kenaikan peningkatana kualitas layanan pustakawan. Sehingga nilai kepuasan pemustaka akan selalu 6,354 apabila kualitas pustakawan tidak terjadi kenaikan sama sekali atau sama dengan nol. Sedangkan nilai koefisien regresi sebesar 0,691 pada $X_{1}$ mempunyai makna setiap terjadi kenaikan kualitas layanan sebesar 1 (satu) maka kepuasan pemustaka meningkat sebesar 0,691. Hal ini mengindentifikasikan bahwa tinggi dan rendahnya nilai kepuasan pemustaka sangat ditentukan sejauh mana kualitas jasa layanan pustakawan yang diberikan terhadap pemustaka. Artinya kepuasan pemustaka sebagai pengguna jasa informasi akan ditentukan oleh kualitas layanan pustakawan penyedia jasa.

Ada berbagai faktor yang mempengaruhi besarnya kontribusi kualitas layanan pustakawan terhadap kepuasan pemustaka diantaranya: 1) Bukti yang terlihat secara langsung seorang pustakawan dalam memberikan layanan terhadap pemustaka yang berwujud kemampuan bicara dalam berkomunikasi, penampilan yang rapi, keterampilan, kejujuran serta dapat melakukan layanan secara pofesional. 2) Kemampuan pustakawan dalam memberikan layanan terhadap pemustaka secara, akurat, tepat, sesuai waktu yang ditentukan, konsisten serta memuaskan pemustaka. 3) mempunyai daya tanggap yang responsif dalam melakukan layanan informasi terhadap pemustaka. 4) Memberikan jaminan pengetahuan, kesopan santunan, komunikasi, kredibilitas, keamanan, kompetensi, pengetahuan, kemampuan, kesopanan, keamanan terhadap pemustaka sehingga pustakawan selalu mendapat kepercayaan dalam melakukan layanan infomrasi. 5) Mempunyai sikap empati terhadap pemustaka dalam melakukan layanan terhadap pemustaka seperti "menjalin komunikasi yang baik, membangun persahabatan, ramah, tanggap dan memahami terhadap kebutuhan pemustaka, kemudahan dalam peminjaman, serta bersikap ramah dan sopan kepada pemustaka". 
Pengaruh Kualitas Layanan Pustakawan ... (Anton Risparyanto)

\section{Pengaruh Kepuasan terhadap Loyalitas Pemustaka.}

Pengaruh kualitas layanan pustakawan terhadap kepuasan pemustaka berdampak pada tingginya loyalitas di perpustakaan. Artinya semakin tinggi tingkat kepuasan pemustaka yang diperoleh dari layanan pustakawan semakin tinggi loyalitas pemustaka di perpustakaan. Berdasarkan hasil uji regresi sebagaimana tercantum pada tabel 4 . Coefficients ${ }^{\mathrm{b}}$ besarnya pengaruh kepuasan terhadap loyalitas pemustaka diperoleh $\boldsymbol{R}$ Square $(0,297 \times 100)$ sebesar 29,7\% dengan nilai sig 0,000 lebih kecil dari pada 0.05 (P-value<0,05). Ini mempunyai makna pengaruh langsung kualitas layanan pustakawan terhadap loyalitas pemustaka sebesar 29,7\% dan signifikan apabila diukur dari loyalitas pemustaka. Sedangkan sisanya 71,3\% dipengaruhi berbagai faktor lain diluar variabel penelitian. Ada beberapa faktor kepuasan pemustaka yang mempengaruhi kontribusi sebesar 29,7\% terhadap loyalitas pemustaka diantaranya: 1) Keluhan pemustaka selalu dapat diatasi dengan baik. 2) Pemustaka merasa puas terhadap semua koleksi yang tersedia dan 3) Semua harapan pemustaka dapat terpenuhi dengan baik. Hasil penelitian ini sejalan dengan pendapat (Yulia Nurendah dan Mumuh Mulyana, 2013) yang menyatakan adanya pengaruh signifikan dan positif kepuasan terhadap loyalitas pemustaka dengan kontribusi sebesar 43,29\%. $\mathrm{Hal}$ ini membuktikan adanya pengaruh yang kuat kepuasan pemustaka terhadap loyalitas pemustaka. Berdasarkan uji signifikan dan pembahasan diatas dapat disimpulkan bahwa pengaruh kepuasan terhadap loyalitas pemustaka signifikan dengan kontribusi sebesar $29,7 \%$.

\begin{tabular}{|c|c|c|c|c|c|c|c|c|}
\hline & \multirow{2}{*}{ Model } & \multicolumn{2}{|c|}{$\begin{array}{l}\text { Unstandardized } \\
\text { Coefficients }\end{array}$} & \multirow{2}{*}{$\begin{array}{c}\begin{array}{c}\text { Standardized } \\
\text { Coefficients }\end{array} \\
\text { Beta }\end{array}$} & \multirow{2}{*}{$\mathrm{t}$} & \multirow{2}{*}{ Sig. } & \multicolumn{2}{|c|}{$\begin{array}{l}\text { Collinearity } \\
\text { Statistics }\end{array}$} \\
\hline & & B & Std. Error & & & & Tolerance & VIF \\
\hline \multirow{3}{*}{1} & (Constant) & 7,977 & 1,331 & & 5,993 &, 000 & & \\
\hline & $\begin{array}{l}\text { Kualitas } \\
\text { Layanan }\end{array}$ & ,113 & ,028 & ,329 & 3,962 &, 000 & ,522 & 1,915 \\
\hline & $\begin{array}{l}\text { Kepuasan } \\
\text { Pemustaka }\end{array}$ & 278 & ,078 & 297 & 3,581 &, 000 & ,522 & 1,915 \\
\hline
\end{tabular}

Sumber: Data Primer Olahan SPSS, 2016

\section{Pengaruh Kualitas Layanan Pustakawan terhadap Loyalitas Pemustaka}

Semakin tingginya nilai kualitas layanan pustakawan akan menentukan tingkat loyalitas pemustaka yang datang di perpustakaan. Hasil penelitian sebagai mana dicantum pada tabel 4 . Coefficients $^{\mathrm{b}}$ bahwa besarnya pengaruh langsung kualitas layanan pustakawan terhadap loyalitas pemustaka dengan $\boldsymbol{R}$ Square $(0,329 \times 100) 32,9 \%$ dan signifikan dengan nilai Sig 0,000 lebih kecil dari pada 0.005 ( $P$ - value $<0,005)$. Ini mempunyai makna bahwa pengaruh langsung kualitas layanan pustakawan terhadap terhadap loyalitas pemustaka signifikan sebesar 32,9\% dan sisanya $66,15 \%$ dipengaruhi faktor lain. Hasil ini dapat diinterpretasikan bahwa semakin baik kualitas layanan yang dilakukan oleh pustakawan maka tingkat loyalitas pemustaka terhadap perpustakan semakin tinggi, tetapi sebaliknya apabila kualitas layanan yang dilakukan oleh putakawan kecil maka loyalitas pemustaka terhadap perpustakaan semakin kecil. Hasil penelitian ini sejalan dengan peryataan (Giarsa Waryaffasya 20017) adanya pengaruh signifikan kualitas pelayanan perpustakaan terhadap loyalitas mahasiswa pada perpustakaan dengan kontribusi sebesar 36,72\%. Berdasarkan pembahasan dan uji signifikan dapat disimpulkan bahwa pengaruh langsung kualitas layanan pustakawan terhadap loyalitas pemustaka signifikan dengan kontribusi 32,9\%. 
Kontribusi Bersama Kualitas Layanan dan Kepuasan Pemustaka terhadap Loyalitas Pemustaka.

Loyalitas pemustaka merupakan pemustaka yang sering melakukan kunjungan rutin ke perpustakaan untuk melakukan pencarian informasi dan peminjaman buku secara teratur, kontinyu dan konsisten di perpustakaan. Disamping itu juga selalu ikut serta menyebarkan dan merekomendasikan kepada semua teman untuk manfaatkan jasa informasi yang tersedia di perpustakaan, walaupun informasi dan buku yang dicari dapat ditemukan di tempat lain. Besarnya tingkat loyalitas pemustaka di perpustakaan secara tidak langsung ditentukan dan dipengaruhi oleh tingkat kualitas layanan pustakawan dengan melalui suatu mediasi oleh kepuasan pemustaka. Sehingga secara bersamaan kedua variabel tersebut mempunyai kontribusi efektif terhadap loyalitas pemustaka. Berdasarkan hasil uji korelasi ketiga variabel sebagaimana tercantum pada tabel tabel 5. Model Summary ${ }^{b}$ diperoleh R Square_(0,331X100\%) 33,1\%. Ini mempunyai arti bahwa, besarnya kontribusi kualitas layanaan pustakawan terhadap loyalitas pemustaka melalui mediasi kepuasaan pemustaka sebesar $33,1 \%$ dan sisanya $66,9 \%$ dipengaruhi faktor lain di luar variabel pengukuran.

Tabel 5. Model Summary ${ }^{b}$

\begin{tabular}{|c|c|c|c|c|c|}
\hline Model & $\mathrm{R}$ & R Square & $\begin{array}{c}\text { Adjusted R } \\
\text { Square }\end{array}$ & $\begin{array}{c}\text { Std. Error of the } \\
\text { Estimate }\end{array}$ & $\begin{array}{c}\text { Durbin- } \\
\text { Watson }\end{array}$ \\
\hline & & & & & \\
\hline 1 &, $576^{\mathrm{a}}$ &, 331 &, 324 & 2,11264 & 1,848 \\
\hline
\end{tabular}

Sumber: Data Primer Olahan SPSS, 2016

Besarnya kontribusi kualitas layanan pustakawan terhadap loyalitas pemustaka melalui mediasi kepuasan pemustaka dapat dijelaskan melalui hasil uji regresi sebagaimana tercantum pada tabel 4. Coefficients ${ }^{b}$ diperoleh persamaan regresi $\hat{Y} 2=7,977+0,329 \times 2+0,297 X 3$. Persamaan regresi ini dapat dimaknai sebagai berikut: 1)
Nilai konstata 7,977 merupakan tingkat loyalitas pemustaka apabila tidak ada perubahan kenaikan kualitas pustakawan maupun adanya respon pemustaka yang merasa puas terhadap layanan yang dilakukan oleh pustakawan sehingga tingkat loyalitas pemustaka tetap sebesar 7,977.2) Koefisien 0,329 mempunyai pengertian bahwa setiap dilakukan perbaikan kualitas layanan pustakawan sebesar satu kali dengan melalui mediasi kepuasan pemustaka tetap maka loyalitas pemustaka secara tidak langsung akan mengalami kenaikan sebesar 0,329. 3) Koefisien 0,297 mempunyai makna setiap terjadi peningkatan mediasi sebesar satu kali maka loyalitas pemustaka bertambah 0,297.

\section{Kesimpulan dan Rekomendasi \\ Kesimpulan}

Setelah dilakukan analisa uji statistik dan pembahasan secara mendalam maka dapat diperoleh beberapa hasil sebagai berikut:

a. Pengaruh kualitas layanan pustakawan terhadap kepuasan pemustaka adalah signifikan

b. Kontribusi kualitas layanan pustakawan terhadap kepuasan pemustaka sebesar $47,8 \%$.

c. Pengaruh kepuasan pemustaka terhadap loyalitas pemustaka signifikan

d. Pengaruh kualitas layanan pustakawan terhadap loyalitas pemustaka dengan mediasi kepuasan pemustaka adalah signifikan.

e. Kontribusi kualitas layanan pustakawan terhadap loyalitas pemustaka yang dimediasi kepuasan pemustaka sebesar 33,1\%.

\section{Rekomendasi}

Berdasarkan hasil penelitian, tulisan ini merekomendasikan kepada Direktorat Perpustakaan untuk meningkatkan kualitas layanan melalui lima hal:

a. Pustakawan harus dapat melayani sesuai dengan yang diharapkan pemustaka. 
Pengaruh Kualitas Layanan Pustakawan ... (Anton Risparyanto)

b. Pustakawan bersikap responsif dan empati terhadap pemustaka sehingga terwujudnya kepuasan dan loyalitas pemustaka.

c. Meningkatkan kemampuan tingkat profesionalisme sehingga pustakawan semakin meningkat kemampuan dan ketrampilannya. Dengan demikian, pustakawan semakin mendapat kepercayaan dari pemustaka.

d. Pustakawan harus dapat menunjukan tingkat profesionalisme yang tinggi dalam melakukan layanan terhadap pemustaka.

\section{Daftar Pustaka}

Basuki, S. 2006. Metode Penelitian. Jakarta: Wedatama Widya Sastra

Daryanto \& Setyobudi, I. 2014. Konsumen dan Pelayanan Prima. Yogyakarta: Gava Media

Dharma, N, dkk. 2013. Hubungan Antara Kualitas Layanan Perpustakaan Undiksha Dan Kepuasan Penggunanya, "Jurnal IImu Sosial dan Humaniora", Vol.2. No. 2, Oktober 2014. Bali: UPT. Perpustakaan Universitas Pendidikan Ganesha Singaraja

Daryono. 2010. Kompetensi Pustakawan Dalam Memberikan Layanan Prima di Perpustakaan Perguruan Tinggi, "Jurnal Kepustakawanan dan Masyarakat Membaca". Vol.26 No.2, Juli-Desember. Palembang: UPT Perpustakaan Universitas Sriwijaya

Hermawan, R. \& Zen, Z. 2006. Etika Kepustakawanan. Jakarta: Sagung Seto

Hurriyati, R. 2005. Bauran Pemasaran dan Loyalitas Konsumen. Bandung: Alfabeta

Irawan, H. 2003. 10 Prinsip Kepuasan Pelanggan. Jakarta: PT Ele Media Komputindo

Jasfar, F. 2012. Teori dan Aplikasi 9 Kunci Sukses keberhasilan Bisnis Jasa SDM, Inovasi, dan Kepuasan Pelanggan. Jakarta: Salemba Empat

Kirom, Bahrun. 2009. Mengukur Kinerja Pelayanan dan Kepuasan Konsumen. Bandung: Pustaka
Rika Cipta

Kotler, Philip. \& Gary Armstrong, G. 2005, Dasar-dasar Pemasaran. Jakarta: Prenhallindo

Lasa Hs,. 2009. Kamus Kepustakawanan Indonesia. Yogyakarta: Pustaka Book Publisher

Marguna, A.M. 2013. “Pengaruh Kualitas Pelayanan Terhadap Kepuasan Pemustaka di UPT Perpustakaan Universitas Hasanuddin", Tesis. Dari http://repository.unhas.ac.id:4001/digilib/ gdl.php? Diakses tanggal 15-1-2016

Musanto, T. 2004. "Faktor-faktor Kepuasan Pelanggan dan Loyalitas Pelanggan: Studi Kasus pada CV. Media Advertising Surabaya", "Jurnal Manajemen dan Kewirausahaan". Vol. 6, No. 2 (2004). Dari http//puslit2.petra.ac.id/ejournal/ index.php/man/article Diakses tanggal 2-3-2016

Nurendah, Y. \& Mulyana, M. 2013. "Analisis Pengaruh Kualitas Pelayanan Perpustakaan Terhadap Kepuasan dan Hubungannya dengan Loyal, Program Studi Manajemen Pemasaran Sekolah Tinggi Ilmu Ekonomi Kesatuan Bogor, Bogor". Dari http://www.academia.edu. Diunduh tanggal 1-2-20017

Purwono. 2014. Profesi Pustakawan. Jakarta: Universitas Terbuka

Qalyubi, S. 2007. Dasar-dasar Ilmu Perpustakaan dan Informasi. Yogyakarta: Jurusan IImu Perpustakaan dan Informasi Fakultas Adab UIN Sunan Kalijaga

Sari, M. P., dkk. 2014. Analisis Pengaruh Kualitas Pelayanan terhadap Kepuasan Pengunjung Perpustakaan, "Jurnal Sistem Informasi JSIKA" Vol. 3, No. 1 (2014). Dari http://jurnal.stikom. edu/index.php/jsika. Diunduh tanggal 1-2-2017 jam 14.300.

Sugiyono. 2009. Metode Penelitian Kuantitatif, Kualitatif dan R \& D, Bandung: Alfabeta

Supranto, J. 2011. Pengukuran Tingkat Kepuasan Pelanggan untuk Menaikan Pangsa Pasar. Jakarta: Rineka Cipta 
Tamara, L. 2014. "Pengaruh Kualitas Layanan Terhadap Kepuasan dan Loyalitas Pemustaka di Perpustakaan Nasional Republik Indonesia". Tesis, Bogor: Sekolah Pasca Sarjana Institut Bogor. Dari http://repository.ipb.ac.id/ handle/123456789/72897 diakses pada tanggal 5-2-2016

Tjiptono, F. 2003. Prinsip-Prinsip Total Quality Sevice; - ed. V, Yogyakarta: Andi

Tjiptono, F. 2005. Pemasaran Jasa. Malang: Bayumedia

Republik Indonesia, 2007. Undang-Uudang Republik Indonesia Nomor 43 Tahun 2007 Tentang Perpustakaan. Jakarta: Sekretariat Negara

Waryaffasya, G. 2013. Pengaruh Kualitas Pelayanan Perpustakaan Terhadap Loyalitas Mahasiswa Program Studi Manajemen S1dan Akutansi S1 Universitas Widyatama, Skripsi, Fakultas Bisnis dan Manajemen Universitas Widyatama, Bandung. Dari, http://repository.widyatama. ac.id Diunduh tanggal 24-12-2016 